\title{
Physicochemical characteristics and pollen spectra of organic and non-organic honey samples of Apis mellifera $\mathbf{L}$.
}

\author{
MARIA JOSIANE SEREIA ${ }^{1}$, ELOI M. ALVES ${ }^{2}$, VAGNER A.A. TOLEDO ${ }^{2}$, \\ LUIS C. MARCHINI ${ }^{3}$, ELIZABETE S. SEKINE ${ }^{2}$, PATRICIA FAQUINELLO ${ }^{2}$, \\ DANIELA DE ALMEIDA ${ }^{3}$ and AUGUSTA C.C.C. MORETI ${ }^{4}$ \\ ${ }^{1}$ Universidade Tecnológica Federal do Paraná (Coordenação de Alimentos), BR 369, Km 05, \\ Caixa Postal 271, 87301-006 Campo Mourão, PR, Brasil \\ ${ }^{2}$ Departamento de Zootecnia, Universidade Estadual de Maringá, Av. Colombo, 5790, 87020-900 Maringá, PR, Brasil \\ ${ }^{3}$ Departamento de Entomologia, Fitopatologia e Zoologia Agrícola da Escola Superior "Luiz de Queiroz", \\ Universidade de São Paulo, Av. Pádua Dias, 11, 13418-900 Piracicaba, SP, Brasil \\ ${ }^{4}$ Instituto de Zootecnia, Sede-Nova Odessa, Rua Heitor Penteado, 56, \\ 13460-000 São Paulo, SP, Brasil
}

Manuscript received on March 24, 2009; accepted for publication on September 15, 2010

\begin{abstract}
The aim of this research was to analyze and compare 17 honey samples, 11 organic and six non-organic Apis mellifera honey. The samples were analyzed concerning moisture, hydroxymethylfurfural, diastase index, water activity, color, total sugar, reducing sugar, sucrose, ash, viscosity, electrical conductivity, $\mathrm{pH}$, acidity, and formol index. With the exception of acidity, reducing sugar and diastase index, the averages of other parameters were different between the two groups. All samples of organic honey presented moisture values between 23.50 and 24.40\%. Among the nonorganic honey samples, two presented apparent sucrose amount upper the maximum limit established by the Brazilian Legislation. According to the quantitative analysis of pollen sediments in the honey samples and frequency of pollen types in 17 honey samples, $41.20 \%$ were classified as unifloral, and the remainder as polifloral.
\end{abstract}

Key words: Honey characterization, melissopalynology, organic honey, physicochemical analysis.

\section{INTRODUCTION}

According to the "Regulamento Técnico de Identidade e Qualidade do Mel" published by "Ministério da Agricultura, Pecuária e do Abastecimento" (MAPA), Instrução Normativa $n^{\circ} 11$ from October $20^{\text {th }}, 2000$ (Brasil 2000), the selected physicochemical tests that characterized the honey according to its maturity are the ones of reducing sugar amount, calculated as inverted sugar, moisture and apparent sucrose. To evaluate the honey purity, are indicated the tests of water insoluble solid quantity, mineral content, and the presence of pollen grains. To check its deterioration, the honey was sub-

Correspondence to: Maria Josiane Sereia

E-mail: josiane@utfpr.edu.br mitted to an acidity test, diastase index, water activity and hydroxymethylfurfural rate.

The Honey Commission from European Community to the "Harmonization Methods" suggests complementary methods to determine the honey quality: electrical conductivity, $\mathrm{pH}$, invertase activity index, protein content (especially proline), formol index, acidity, viscosity or specific rotation index (Bogdanov et al. 1997). Associated to these parameters, the understanding of the property known as water activity (Aw) guarantee a more appropriated evaluation to the honey quality. The Aw being equivalent to the balance relative moisture (Koop 2002) represents the effective molar fraction of the water in the sample. Its quantification is really important, once food as honey, with different 
combinations of micro-structured resources, would depend on time and temperature to present water migration from areas with high Aw to areas with low Aw (Koop et al. 2000, Koop 2002), modifying its chemical composition.

Several studies to evaluate honey quality produced in Brazil have been conducted (Mendonça et al. 2008, Tosi et al. 2008), and the results were compared to the standard of international official organs established by the countries (Marchini and Souza 2006).

The organic honey certification has different characteristics, since it is a pesticide-free product and well appreciated in the international market. The basic requirement is the ability to control the product origin and the production routine (Buainin and Batalha 2007).

This research was carried out to evaluate the physicochemical and melissopalynological characteristics in organic honey samples produced by Apis mellifera L. in the region of the triple border (Paraná, São Paulo and Mato Grosso do Sul States), and non-organic honey samples from Paraná State, and to compare the results with the established standard honey by the national official organization MAPA (Brasil 2000) and the international standard (Codex Alimentarius 2001).

\section{MATERIALS AND METHODS}

\section{Collection of Samples}

Honey samples were analyzed and compared: 11 of organic honey and six non-organic, respectively, harvested in islands of the triple border (among Paraná, São Paulo and Mato Grosso do Sul States) and from Paraná State, from December 2004 to January 2005. The samples were identified by the letter "O" and "NO" to the organic and non-organic honey samples respectively, followed by a number.

The climate of the region, according to the Köppen classification, is temperate humid, with hot summers "Cfa" (Maak 1968). The non-organic honey samples were collected by beekeepers in the northeast of Paraná State. According to the Meteorological Center at "Universidade Estadual de Maringá", the regional climate is tropical temperate, presenting rainy summers and dry winter.

\section{PhysicochemiCAL ANALYSIS}

The $\mathrm{pH}$, acidity (meq. $\mathrm{kg}^{-1}$ ), total reducing sugar (TS), reducing sugar (RS), apparent sucrose (\%), protein (\%), ash content (\%), hydroxymethylfurfural $\left(\mathrm{mg} \cdot \mathrm{kg}^{1}\right)$, diastase index (Goth scale), moisture (\%) and color (mm) were verified according to the AOAC method (1990) and Marchini et al. (2004). The electrical conductivity $\left(\mu \mathrm{S} . \mathrm{cm}^{-1}\right)$ was obtained according to Bogdanov et al. (1997). The formol index ( $\left.\mathrm{mL} \cdot \mathrm{kg}^{-1}\right)$ was determined according to the method of Moraes (1994). The viscosity (Cp) was determined according to G. Campos (unpublished data), and the water activity (Aw) determination was made in a water activity meter.

Although the Brazilian legislation does not consider values for total reducing sugar, electrical conductivity, $\mathrm{pH}$, formol index, protein, viscosity and water activity, these analyses were accomplished and used to complement the characterization of the honey samples.

\section{Pollen ANALysis}

The pollen analysis is a great tool that may be used to detect organic honey because it helps to identify the plants visited by honeybees.

All honey samples were prepared using the acetolysis method (Erdtman 1952, Louveaux et al. 1978). The method consists in the acid treatment of the honey sample, followed by sediment washing and centrifugation. Reminiscent residues are distributed in a glass lamina with hot glycerinated gelatin, followed by sealing with paraffin.

The qualitative analysis was determined by comparisons with specialized literature (Barth 1970a, b, c). The quantitative analysis was done by counting 300 pollen grains in the plate (Louveaux et al. 1978): dominant pollen ( $>45 \%$ of total pollen grains $-\mathrm{DP})$, accessory pollen (16 to $45 \%$ - AP), important isolated pollen ( 3 to $15 \%$ IIP) and occasional isolated pollen $(<3 \%-$ OIP $)$.

\section{DATA ANALYSIS}

The data were statistically analyzed using the soft-

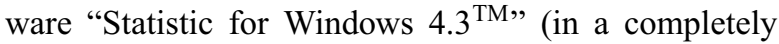
randomized design), the variance analysis and $F$ test $(\mathrm{P}<0.05)$, with three repetitions to each parameter, obtaining the averages, standard deviation, coefficient of 
variation, summary of variance analysis and probability. To the grouping analysis, it was used the average Euclidean distance for each honey type (O and NO), the 13 physicochemical parameters selected, and pollen types that influenced in the distinction of the studied honey.

\section{RESULTS}

The physicochemical data obtained for the organic and non-organic honey samples are presented in Table I. Table II presents pollen spectra and classified them as dominant, accessory, isolated or important isolated pollen to the honey samples.

\section{DISCUSSION}

\section{PHYSICOCHEMICAL ANALYSIS}

The values of $\mathrm{pH}$ differed $(\mathrm{P}<0.05)$ between the two groups of honey. The $\mathrm{pH}$ in the organic and non-organic honey presented a mean of 3.87 , with minimum and maximum values of 3.84 and 3.91 , respectively, and of 4.15 , with minimum and maximum values of 3.90 and 4.40, respectively. C.M.F. Arruda (unpublished data), G.S. Sodré (unpublished data) and Mendonça et al. (2008), by analyzing Brazilian honey samples of different floral origins, reported $\mathrm{pH}$ values from 3.80 to 4.90. In the Savannah area of Mato Grosso do Sul and São Paulo States, these values varied from 3.40 to 4.50 (G.H.C. Vieira unpublished data), and from 3.30 to 4.90 (Almeida-Anacleto and Marchini 2004).

This result is due to particularities of blossom composition in the collection area, once the $\mathrm{pH}$ of honey may be influenced by nectar $\mathrm{pH}$ and differences in soil composition, or associated with a vegetal species (Crane 1985).

Another factor that is associated with and explains the minor values of $\mathrm{pH}$ observed in organic honey samples is the glucose oxidase activity, which is favored by the smallest content of hydrogen peroxide and glycolic acid (J.E. Tello Durán et al., unpublished data).

On the other hand, the acid $\mathrm{pH}$ may favor a more complex sugar formation from fructose (Doner 1977). In this way, the fructose would be consumed by the yeast, which would produce acid compounds, the ones that would decrease the $\mathrm{pH}$ with the reduction of the fruc- tose content. The $\mathrm{pH}$ values in this research are superior to the ones found by G.S. Sodré (unpublished data).

The averages obtained to the acidity did not differ $(\mathrm{P}>0.05)$ between the two analyzed groups. Organic honey presented a mean content of 27.29 meq. $\mathrm{kg}^{-1}$, with minimum and maximum values of 24.09 and 32.33 meq. $\mathrm{kg}^{-1}$, respectively, and non-organic honey of 26.77 meq. $\mathrm{kg}^{-1}$, with minimum and maximum values of 12.79 and 33.93 meq. $\mathrm{kg}^{-1}$, respectively.

L.C. Marchini (unpublished data), G.S. Sodré (unpublished data) and Mendonça et al. (2008) reported variations for acidity values from 5.00 to 56.00 meq. $\mathrm{kg}^{-1}$. The acidity origin is partly due to the action of the enzyme glucose oxidase, which originates the gluconic acid (J.E. Tello Durán et al., unpublished data).

Further acidity originated from honey is due to the organic acid variation caused by different nectar sources (White Junior 1975), the action of bacteria during the honey maturation and the quantity of mineral present in honey (Tysset and Rousseau 1981).

According to the legislation of MAPA (Brasil 2000), the free acidity in honey must not be superior to 50 meq. $\mathrm{kg}^{-1}$. All analyzed samples (organic and nonorganic) agree with the quality standards to the market consumer.

The average content of reducing sugars was $72.75 \%$, with minimum and maximum values of 70.42 to $75.75 \%$, and $68.86 \%$, with minimum and maximum values of 64.24 to $73.34 \%$, respectively, to organic and non-organic honey. These values are similar to the ones determined by Mendonça et al. (2008) who worked with honey samples produced by $A$. mellifera in a fragment of Savannah in Itirapina, São Paulo (60.90 to 71.50\%), while C.M.F. Arruda (unpublished data), G.H.C. Vieira (unpublished data), and Komatsu et al. (2002) show a greater variation in the content of reducing sugars (53.20 to $87.30 \%)$. The sugars and water are the main components of honey. The monosaccharides fructose and glucose represent $80.00 \%$, and the disaccharides sucrose and maltose only $10.00 \%$ of total of the sugars. The content of these different sugars may provoke physical alterations in honey, such as viscosity, density, hygroscopicity and crystallization (White Junior 1975).

Flechtmann et al. (1963), studying samples of commercial honey of Eucalyptus flowers, orange tree 


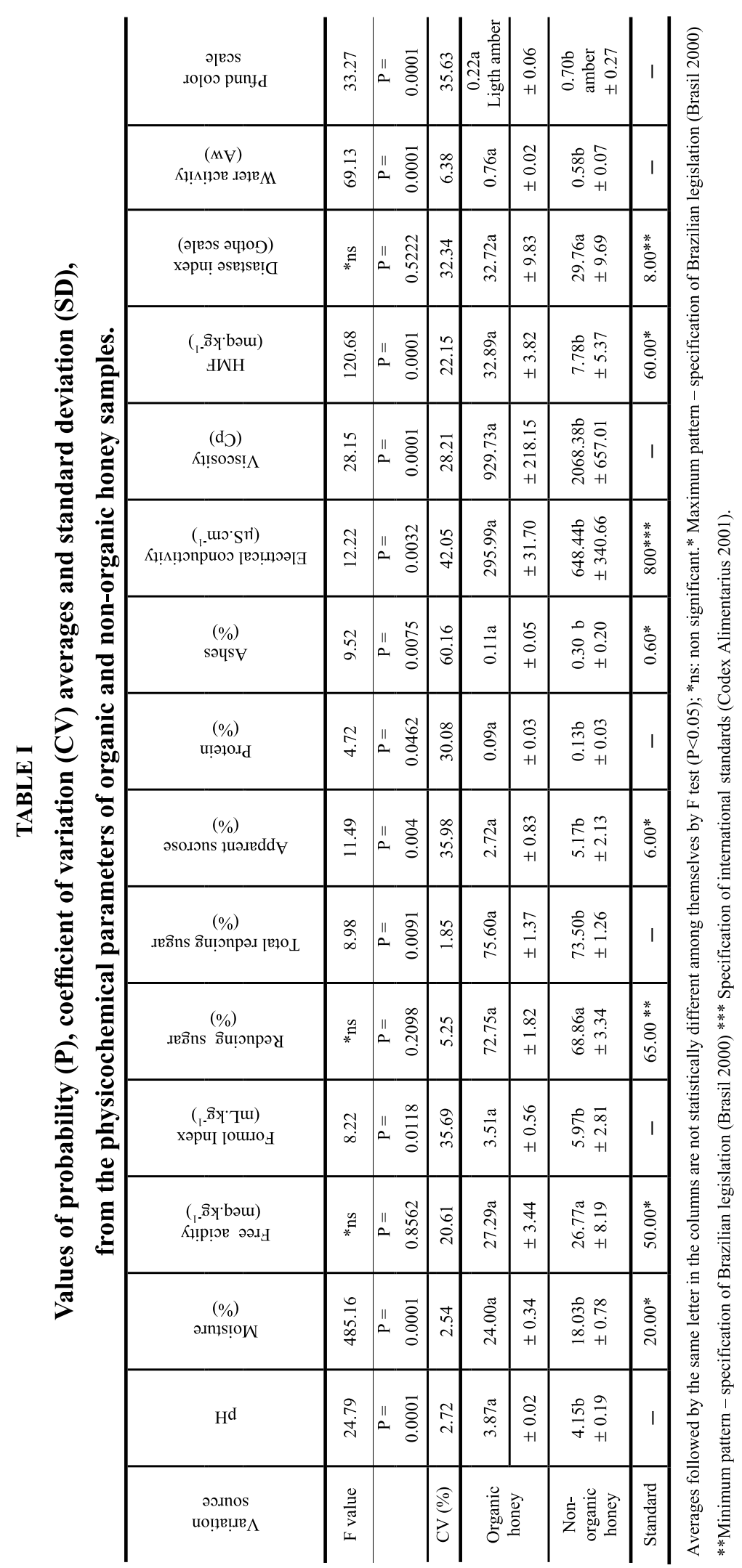


TABLE II

Pollen spectra of organic and non-organic honey samples of $\boldsymbol{A}$. mellifera after quantitative and qualitative analyses of pollen sediments.

\begin{tabular}{|c|c|c|c|c|c|c|c|c|c|c|c|c|c|c|c|c|c|}
\hline \multirow{2}{*}{$\begin{array}{l}\text { Family of } \\
\text { floral source }\end{array}$} & \multicolumn{11}{|c|}{ Organic honey samples } & \multicolumn{6}{|c|}{$\begin{array}{l}\text { Non-organic honey } \\
\text { samples }\end{array}$} \\
\hline & $\begin{array}{l}\overline{0} \\
0\end{array}$ & $\begin{array}{l}1 \\
0 \\
0\end{array}$ & $\begin{array}{l}\text { ô } \\
\text { ô }\end{array}$ & $\begin{array}{l}\text { t } \\
0\end{array}$ & $\begin{array}{l}n \\
0 \\
0\end{array}$ & $\begin{array}{l}0 \\
0 \\
1\end{array}$ & $\begin{array}{l}\hat{s} \\
1 \\
0\end{array}$ & $\begin{array}{l}\infty \\
\stackrel{1}{1} \\
0\end{array}$ & $\begin{array}{l}\text { ò } \\
\text { o }\end{array}$ & $\frac{0}{1}$ & $\overline{0}$ & $\begin{array}{l}\overline{0} \\
\vdots \\
\text { Z }\end{array}$ & $\begin{array}{l}\text { Ò } \\
\text { 1 } \\
\text { Z }\end{array}$ & $\begin{array}{l}0 \\
1 \\
0 \\
z\end{array}$ & $\begin{array}{l}\text { ¿ } \\
\text { 1 } \\
Z\end{array}$ & $\begin{array}{l}n \\
0 \\
0 \\
0 \\
z\end{array}$ & $\begin{array}{l}\text { oे } \\
\text { 1 } \\
\text { Z }\end{array}$ \\
\hline Asteraceae & PI & & & & & & & & & & PI & & & & & & \\
\hline Euphorbiaceae & $\mathrm{PD}$ & & PD & & $\mathrm{PD}$ & & & & & & $\mathrm{PD}$ & PI & PI & & & & \\
\hline Mimosaceae & PI & PI & PI & PI & PI & PI & PI & PI & PI & PI & PI & & PA & & & PD & PA \\
\hline Myrtaceae & PII & PA & PII & PA & PII & PA & PA & PA & PA & PA & PII & $\mathrm{PD}$ & $\mathrm{PA}$ & PII & PA & PII & PII \\
\hline Polygonaceae & & & & & & & & & & & & PII & & & & & \\
\hline Sapindaceae & & & & & & & & & & & & & & & PII & & \\
\hline Solanaceae & & & & & & & & & & & & PA & PA & PI & PA & PII & PD \\
\hline
\end{tabular}

flowers and others from seven cities in São Paulo, obtained values from 80.02 to $83.80 \%$ for reducing sugars contents, which are above the ones found in this study. Huidobro and Simal (1984) obtained to honey samples of orange tree flowers $75.90 \%$, and of wild flowers $75.70 \%$.

The highest levels of Aw found for organic honey samples are directly related to the highest diastase index, which is responsible for the reaction catalyze. Comparing the two groups considering the average obtained to the moisture, it can be inferred that the Aw was favored by the higher water humidity in organic honey samples (Table I).

The apparent sucrose in the organic and non-organic honey presented an average of $2.72 \%$, with minimum and maximum values of 1.15 to $3.91 \%$, and $5.17 \%$, with minimum and maximum values of 3.09 to $8.84 \%$, respectively. Two samples presented higher sucrose content than the standard established by MAPA (Brasil 2000) in non-organic honey, and the maximum percentage allowed in honey from nectar is $6.00 \%$ of sucrose.

Mendonça et al. (2008) reported that the proportion of sucrose in honey must be around 0.40 to $3.50 \%$. When this value is too higher, it becomes an indicative that the product is unripe or adulterated, and that the transformation of sucrose in glucose and fructose by invertase did not happen.

The formol index differed $(\mathrm{P}<0.05)$ between the two analyzed groups: the organic honey presented a mean content of $3.51 \mathrm{~mL} \cdot \mathrm{kg}^{-1}$, with minimum and maximum values of 2.91 and $4.53 \mathrm{~mL} \cdot \mathrm{kg}^{-1}$, respectively, and the non-organic honey of $5.97 \mathrm{~mL} \cdot \mathrm{kg}^{-1}$, with minimum and maximum values of 3.20 and 9.60 $\mathrm{mL} . \mathrm{kg}^{-1}$, respectively.

The results obtained in this study are similar to the ones observed by Huidobro and Simal (1984), who informed that the formol index in honey represents, predominantly, the amine compounds related directly with the content in peptides, protein and amino acids, and is a good indicative of the presence of nitrogen in the honey.

G.S. Sodré (unpublished data) and Mendonça et al. (2008) reported formol index values from 4.00 to $16.70 \mathrm{~mL} \cdot \mathrm{kg}^{-1}$ for Brazilian honey of different floral origins. In the Savannah area of São Paulo and Mato Grosso do Sul States, these values varied from 3.50 to $19.00 \mathrm{~mL} \cdot \mathrm{kg}^{-1}$ (Almeida-Anacleto and Marchini 2004), and from 5.00 to $16.00 \mathrm{~mL} . \mathrm{kg}^{-1}$ (G.H.C. Vieira, unpublished data), respectively.

Significant differences occurred among the averages for protein from organic and non-organic honey 
samples. In organic honey, the mean content was $0.09 \%$, with minimum and maximum values of 0.04 to $0.18 \%$, and in non-organic honey was $0.13 \%$, with minimum and maximum values of 0.10 to $0.17 \%$, respectively.

According to Bath and Singh (1999), the variation for protein in honey occurred in function of the floral origin, with averages of 0.04 to $0.65 \%$ for Helianthus annuus and Eucalyptus lanceolatus flowers, respectively. In Brazil, A.D. Amaral et al. (unpublished data) reported values from 2.54 to $2.79 \%$ to the honey of Eucalyptus and orange tree flowers, respectively. These values were superior to the ones observed in this study (0.4 to $0.6 \%)$. Archenti (1984) verified a protein content of $0.18 \%$ to Argentine honey, which is superior to the protein content found in this research. Peng and Pan (1994) observed variations between 0.05 and $0.42 \%$ to the protein content in the honey of Ziziphus jujuba, Astragalus sinicus and Sesame sp. flowers, among others. G.S. Sodré (unpublished data), by analyzing honey samples from Ceará and Piauí States, reported averages of 0.35 and $0.19 \%$, respectively.

Mendonça et al. (2008) reported protein values from 0.13 to $1.00 \%(0.67 \pm 0.25 \%)$ for Brazilian honeys of different floral origins. In a Savannah area of Mato Grosso and São Paulo States, these values varied from 0.11 to $0.54 \%$ (G.H.C. Vieira, unpublished data), and from 0.07 to $0.37 \%$ (Almeida-Anacleto and Marchini 2004), respectively.

Pollen grains, can fall into the flower, where there is nectar accumulated. In other occasions, during the visitation of the flower, the bee touches the anther and becomes impregnated with pollen, "contaminating" the nectar that will be intaken. Because of this, in general, there are pollen grains into the honey (Faegri and Van Der Pijl 1979).

The smallest protein content observed in organic honey samples can be explained by local climatic conditions, as well as by the morphologic and physiologic characteristics of the flowers that were used by the worker honeybee as a resource. In the first case, the rain excess when the honey is produced can cause pollen dilution by lixiviation of the flowers and, consequently, the reduction of the protein content in the analyzed samples. In the second case, as the pollen grains appear naturally in the nectar of the flowers, the quanti- ties differ depending on the position and the maturity of the anther in relation to the same nectary of the flower; if they are compatible, the pollen gets into the nectar and both are collected by the worker honeybee (Todd and Vansell 1942).

The average content of obtained ashes differed $(\mathrm{P}<0.05)$ between the two analyzed groups. The organic honey presented an average content of $0.11 \%$, with minimum and maximum values 0.06 to $0.24 \%$, and non-organic honey an average of $0.30 \%$, with minimum and maximum values of 0.15 to $0.67 \%$.

The ashes percentage is similar to the one determined by Marchini et al. (2001) in honey from five species of Eucalyptus. Sodré et al. (2005) analyzed 58 honey samples harvested in Ceará (20 samples) and Piauí (38 samples) States and Mendonça et al. (2008), by analyzing honey samples from a fragment of Brazilian Savannah in Itirapina reported ashes values from 0.04 to $1.02 \%(0.52 \pm 0.35 \%)$ for the Brazilian honey of different floral origins. In the Savannah area of Mato Grosso do Sul and São Paulo States, these values varied from 0.10 to $0.68 \%$ (G.H.C. Vieira, unpublished data), and 0.02 to $0.77 \%$ (Almeida-Anacleto and Marchini 2004), respectively.

Only the sample NO-01 presented a superior content $(0.60 \%)$ to the maximum limit allowed by the legislation established by MAPA (Brasil 2000). This value may have a relation with some honey irregularities, as the lack of hygiene and decantation, smoke excess and/or filtration in the honey processing. The method is based on the principle that all organic substances submitted to high temperatures turn in to gases that are dissipated in to the atmosphere. The residue is quantified as ashes (Lasceve and Gonnet 1974).

In Brazil, mainly in the sugarcane regions, the honeydew production occurs, in which the worker honeybee takes sweet substances out of the sugarcane and turn them in to honey that is rich in mineral salt and vitamins. This is the explanation to the high ash content found in the non-organic honey sample (NO03 ) from a region where this culture is extensively cultivated. According to Frias and Hardisson (1992), it can be used as an indicator of the honey authenticity, signifying adulteration with artificial products.

The averages obtained by electrical conductivity 
differed $(\mathrm{P}<0.05)$ between the two analyzed groups. In organic honey, the average was $295.99 \mu{\mathrm{S} . \mathrm{cm}^{-1}}^{\text {, }}$ with minimum and maximum values of 266.70 to $342.00 \mu{\mathrm{S} . \mathrm{cm}^{-1}}^{1}$, respectively, and in non-organic honey, the average was $648.44 \mu \mathrm{S} . \mathrm{cm}^{-1}$, with minimum and maximum values of 346.66 to 1248.33 $\mu \mathrm{S} . \mathrm{cm}^{-1}$, respectively.

G.S. Sodré (unpublished data), by analyzing honey samples from Bahia State, reported an average of $780.70 \mu \mathrm{S} . \mathrm{cm}^{-1}$, and by analyzing samples of commercial honey of Eucalyptus, obtained an average of $1018.65 \mu \mathrm{S} . \mathrm{cm}^{-1}$. Bogdanov (1999) verified that the values of electrical conductivity have a direct relation with the mineral and apparent sucrose content of the analyzed samples.

Mendonça et al. (2008) reported electrical conductivity values from 227.30 to $1851.30 \mu \mathrm{S} . \mathrm{cm}^{-1}$ (1081.4 $\pm 600.8 \mu \mathrm{S} . \mathrm{cm}^{-1}$ ) for Brazilian honeys of different floral origins. In a Savannah area of Mato Grosso do Sul and São Paulo States, these values varied from 284.00 to $2200.00 \mu$ S.cm ${ }^{-1}$ (G.H.C. Vieira, unpublished data, Marchini et al. 2004). These results corroborate the ones obtained in this research.

The non-organic honey samples presented a direct relation with the high sucrose and mineral content, possibly because they were originated from the more concentrated nectar, with more elevated content of mineral and sugar (Table I). For viscosity $(\mathrm{Cp})$, the averages differed $(\mathrm{P}<0.05)$ between the two groups of honey. In organic honey, the average was $929.73 \mathrm{Cp}$, with minimum and maximum values of 633.40 to $1113.40 \mathrm{Cp}$, respectively, and for non-organic honey the average was $2068.38 \mathrm{Cp}$, with minimum and maximum values of 846.70 to $2533.40 \mathrm{Cp}$, respectively. These results corroborate the ones reported by Seemann and Neira (1988), C.M.F. Arruda (unpublished data), G.S. Sodré (unpublished data), G.H.C. Vieira (unpublished data) and Mendonça et al. (2008), in which the viscosity value was inversely dependent on the water content presented by the samples, as they are linked to the relative density (Table I).

The organic honey presented less viscosity because there is a smaller internal friction of the molecules, which is determined by a higher moisture content or fluid grade. This composition defined the re- ological behavior of the organic honey samples that, being less aggregated, stand at a smaller opposition strength of the viscosimeter when compared to the non-organic honey, which is more viscous.

The averages of hydroxymethylfurfural (HMF) differed $(\mathrm{P}<0.05)$ between the two groups. The average of non-organic honey was $32.89 \mathrm{mg} . \mathrm{kg}^{-1}$, with a range of 28.79 to $38.77 \mathrm{mg} \cdot \mathrm{kg}^{-1}$, while for the non-organic honey the average was $7.78 \mathrm{mg} \cdot \mathrm{kg}^{-1}$, with a range of 2.02 to $17.18 \mathrm{mg} \cdot \mathrm{kg}^{-1}$. In general, even showing differences among them, the honey samples were within the standards for direct human consumption.

In studies accomplished by Dayrell and Vital (1991) and Mendonça et al. (2008) with samples of Brazilian honey produced by A. mellifera, the HMF values varied from 1.1 to $248.2 \mathrm{mg} \cdot \mathrm{kg}^{-1}$. According to Evangelista (2000), enzymatic substances that are put into the nectar during the transportation to the hive are also a factor that can lead to a change on the HMF concentration.

According to Frias and Hardisson (1992), when the A. mellifera honey is heated in excess or kept in conditions of high environmental temperatures, HMF is formed by certain sugar decomposition in livilinic and formic acid, contributing to higher acidity values.

In this study, it was observed that the organic honey presented predominantly light color and high content of HMF if compared to non-organic honey, corroborating Bianchi (1989) who verified that the dark honey (Eucalyptus and wild) does not always present high values of HMF in relation to the light honey. A possible explanation is referred to the higher local temperature in the region of the triple frontier in relation to temperature that was studied. According to the trimester prognostic - December 2004, January-February 2005 of INMET (2005) - the hot and wet air masses predominated during this period, favoring high temperatures that varied from $30^{\circ} \mathrm{C}$ to $33^{\circ} \mathrm{C}$.

According to Toledo and Nogueira-Couto (1999), there is an effective control of the temperature in the nest with the brood by the workers through the ventilation. In the super, hot air accumulation difficult the ventilation, which probably has an influence on the honey quality in the comb, thus causing higher dehydration of hexose (fructose) and higher content of HMF 
in the samples of organic honey in relation to the nonorganic honey (Bobbio and Bobbio 1999).

To summarize, the higher formation of HMF in the studied samples of organic honey occurred because of three associated factors: higher environmental temperature, high Aw of honey and high activity of glucose oxidase (which favors the $\mathrm{pH}$ decrease). It is worth mentioning that the reaction of certain sugars to acids occurs in the presence of free water (Aw).

The averages for the content of diastase index do not differ $(\mathrm{P}>0.05)$ between the two groups. The average of the diastase index in non-organic honey was 29.76 (Gothe scale) to an interval from 16.31 to 38.83 , while organic honey presented an average of 32.72 to an interval from 12.50 to 38.83 . These results are similar to those observed by Almeida-Anacleto and Marchini (2004) with samples from São Paulo State. Costa Leite et al. (1999) and Sodré et al. (2005) observed that one sample (4.17\%) showed a value below the minimum set by the legislation, which is eight in diastase index on Gothe scale. However, in this study, all analyzed samples had a diastase index within the required standard.

Although there are no values established by MAPA (Brasil 2000) for the analysis of this parameter, the results obtained in the present research are similar to the ones determined by L.C. Marchini (unpublished data).

Costa Leite et al. (1999) and G.S. Sodré (unpublished data) reported indexes from 13.00 to 62.81 (Gothe scale), with averages of 32.05 and 34.11 , respectively, and, however, similar to the ones of this work. G.S. Sodré (unpublished data) observed in 58 honey samples of $A$. mellifera values from 5.30 to 43.39 (Gothe scale).

According to Tosi et al. (2008), this changing behavior makes the diastase index an uncertain parameter to determine if honey has been submitted to heating.

The higher values of diastase index verified in organic honey samples are explained by the fact that they were originated from the rich nectar flow, although, with a low sugar content, they would need an intense processing and more time to be converted into honey. White Junior (1994) observed that the honey produced in hot and dry regions presented smaller quantities of enzymes than the ones from hot and wet regions, as verified in this study. In practice, it was observed that the diastase index is independent of the HMF content in the samples (Table I).

The averages obtained by water activity differed $(\mathrm{P}<0.05)$ between the two groups. The medium content of water activity in organic honey was 0.76 to an interval from 0.74 to 0.79 , while the non-organic honey was 0.58 to an interval from 0.51 to 0.67 . The importance of this determination is that water is the major component of many foods and has an influence in their biochemical and microbiological stability. This value is used to define the food potential risk, critic point control, determination of storage conditions, package kind and validity period of processing (Isengard 2001).

In this study, the medium values to Aw were low enough to inhibit completely the growing of bacteria from coliform group, which present their maximum growing rate when Aw $>0.91$ (Bobbio and Bobbio 1999). Meanwhile, in all studied samples, when the values were superior to 0.65 , they help the fungi growing, showing that the inhibition by the osmotic effect of the honey was dependent on the species of the studied microorganisms.

On the other hand, the water activity reflects a combination of water-solute by the interaction of the capillary force. In this way, the other explanation refers to the nature of the hydrocolloids, protein polymeric chain, concentration and sorts of ions present in honey, which may affect the water activity by linking the mixture and reducing the activity (Dunne and Reuben 1995, Trombetta et al. 2005).

Non-organic honey is richer in minerals, proteins and sugar than organic honey, which, consequently, allows a bigger molecular interaction (water-solute) and the reduction of the availability of the molecules of water that are important to microbial growing in these samples. It is determined by the floral origin, and it can be influenced by processing and storage, once the storage time, light, heat and possible enzymatic reactions can affect this physical property (Flechtmann et al. 1963).

The values of moisture differed $(\mathrm{P}<0.05)$ between organic and non-organic honey samples. Organic honey presented the mean moisture content of $24.00 \%$ and an interval from 23.50 to $24.40 \%$. These values are super- 
ior to the maximum limit allowed by the legislation, which is $20.00 \%$, established by MAPA (Brasil 2000).

The average moisture was $18.03 \%$ from 17.30 to $19.50 \%$ of variation in non-organic honey. C.M.F. Arruda (unpublished data), G.S. Sodré (unpublished data) and Mendonça et al. (2008) reported moisture values from 15.00 to $22.90 \%$ for Brazilian honey of different floral origins. In a Savannah area of Mato Grosso do Sul and São Paulo States, these values varied from 15.70 to $26.00 \%$ (G.H.C. Vieira, unpublished data) and from 16.60 to $20.80 \%$ (Almeida-Anacleto and Marchini 2004).

Comparing the moisture in organic honey with the one in non-organic honey, it can be deduced that the highest moisture content observed in the organic honey was due to the climatic conditions (not evaluated) in the studied area. In these places (islands), the summer is hot and rainy, which results in honey with high moisture because of the air saturation and the big nectar flow that happens after the rains. This can constitute a difficulty to the forager when removing the water (P.R.G. Noronha, unpublished data). This confirms the observation made by the beekeepers that the honey produced in the beginning of the year is more watery and can be associated to small nectar concentrations.

According to Faria (1993), the highest moisture content is also verified in unsealed honey, which is harvested from the combs that did not have their alveoli completely sealed by the honeybees. In this case, the honey presents a higher moisture content. Thus, even the sealed honey may have levels upper to $20.00 \%$ if the apiary is located in a region with air relative moisture $(\mathrm{RH})$ superior to $60.00 \%$. Data from INMET registry (2005) revealed to this region a $\mathrm{RH}$ between $70.00-90.00 \%$. These values may still be related to fails like bad asepsis during the extraction, manipulation, packing and conditioning in non appropriated place (P.R.G. Noronha, unpublished data).

The centrifugation may contribute negatively to the honey quality. The extractor pulverizes the honey in micro particles, favoring the absorption of the water from the air by the formation of a big surface related to the volume and causing the increase of the water free from the honey. In rainy months, the ideal place would have a dehumidifier, once all the honey with the mois- ture above $20.00 \%$ is subjected to fermentation (Stonoga and Freitas 1991). Non-organic honey is richer in minerals, proteins and sugar than the organic honey, which, consequently, allows a bigger molecular interaction (water-solute) and the reduction of the availability of the molecules of water that are important to microbial growing in these samples. In this research, two samples of non-organic honey did not overtake the values of reducing sugar and sucrose established by the Brazilian legislation, and it becomes an indicative that the product is unripe or adulterated.

In organic honey, $100.00 \%$ of the samples did not overtake the values of moisture established by the Brazilian legislation, and they were responsible for the reduction of the viscosity, $\mathrm{pH}$, and the increasing of the liquid phase (low osmotic pressure), acid formation and HMF. For color analysis, the obtained values are similar to the ones determined by Almeida-Anacleto and Marchini (2004), G.S. Sodré (unpublished data), and Mendonça et al. (2008). The organic honey presented a significantly lighter color, ranging from extra light amber to light amber, which guarantees more acceptability and a better price in the market, while in nonorganic honey the amber coloration predominates.

\section{Pollen ANALysis}

According to the quantitative analysis of the pollen sediment and the frequency of the pollen types, $41.20 \%$ were classified as unifloral and the rest as multifloral.

In organic honey, $63.60 \%$ of the samples were classified as multifloral, and $36.4 \%$ as unifloral (Euphorbiaceae), inferring that, in forest environments, the nectar collection occurs in several plants, and that the forest fragment constitutes a sustainable reserve for the organic apiculture.

Considering the unifloral organic honey, it was observed a higher frequency of pollen grains and plants of Euphorbiaceae (Croton urucurana), with a considerable participation in honey composition, from the region of the island in the triple frontier. The Croton include vegetables like trees or bushes, with few of herbage height, whose pollen grains present a characteristic pollen morphology (Lorenzi 2000).

In the constitution of the multifloral organic honey, 
it was observed a higher frequency of pollen grains from plants of Mimosaceae (Anadenanthera peregrina) and Myrtaceae (Eucalyptus sp.) commonly found in forest environments, which proves the importance of these families as main sources of the nectar and pollen in Southwest Brazil. In regions where the vegetation is more open as Cerrado and in degraded soils with higher moisture, typical from forest borders and big glades, the blossoming happens in September and October (Lorenzi 2000, Mendonça et al. 2008), when the samples were collected. According to Carvalho and Marchini (1999), Mimosaceae family consists of about 60 genera represented by 3000 species distributed mainly in tropical and subtropical regions, and is considered by Ramalho et al. (1990) as one of the main families that keeps the honey bee.

In non-organic honey, $50.0 \%$ of the samples were classified as multifloral, and $50.0 \%$ as unifloral. The wild flora contributes to the production of a big variety of honey types around the world. There is an important role to the sustainability of the apiculture because it represents a continuous food offering, which supplies the lack of blossom in the monoculture. This value is not the only aspect that justifies the preservation or maintenance of flora in small areas. Other native pollinators, including hundreds of bee species, are beneficiated by this preservation for an effective stock to the pollination of agricultural crops (Robinson et al. 1989, Southwick and Southwick 1992). Honey bees pollinate one or more cultivars of $>66.00 \%$ of the world's 1.500 crop species (Roubik 1995) and are responsible for 15.00 to $30.00 \%$ of food production (McGregor 1976).

The unifloral non-organic honey presents pollen grains mainly from Myrtaceae (Eucalyptus sp.) and Mimosaceae (Anadenanthera peregrina). In the multifloral kinds, pollen grains were observed from the families Euphorbiaceae (Croton urucurana), Mimosaceae (Anadenanthera peregrina), Myrtaceae (Eucalyptus sp.), Polygonaceae, Sapindaceae and Solanaceae. The importance of Eucalyptus sp. as a food resource of A. mellifera was also reported by D. Almeida (unpublished data) and G.H.C. Vieira (unpublished data) in Savannah areas in state of São Paulo and Mato Grosso do Sul, respectively.

The importance of Euphorbiaceae as a source of
Apis mellifera food was reported by G.H.C. Vieira (unpublished data), in a Savannah area of Mato Grosso do Sul. D. Almeida (unpublished data), in a Savannah area in the Pirassununga county (SP), reported the predominance of pollen of Myrtaceae and Mimosaceae. Barth (2004) analyzed samples of honey and pollen from an area of the state of Rio de Janeiro and reported the Mimosaceae and Asteraceae families as the most frequent ones in honey samples, whereas in pollen samples, Asteraceae, Euphorbiaceae, Fabaceae and Myrtaceae families were predominant.

For organic honey, seven samples were from two families of plants, Myrtaceae and Mimosaceae, and the other samples were from Euphorbiaceae, with a great pollen diversity from Asteraceae, Myrtaceae and Mimosaceae. This shows a relation between the beginning of rainy period (October) and the increasing of the variety of available floral resources that are used by honeybees. In a general way, the organic honey was classified as multifloral, being originated from several families of plants, and non-organic honey as unifloral, originated mainly from the Myrtaceae, Solanaceae and Mimosaceae family.

\section{Analysis of Grouping to the Physicochemical Parameters and Pollen Types}

To analyze the grouping of the principal compounds of 13 physicochemical parameters and pollen types, the following factors were selected: $\mathrm{pH}$, moisture, acidity, formol index, reducing sugar, total reducing sugar, sucrose, protein, ashes, HMF, diastase index, water activity, color, and pollen types.

Using the criteria proposed by Joliffe (1973), parameters as electrical conductivity and viscosity were disposable, due to the high correlation presented, respectively, with the content of ashes and moisture. The data of cluster analysis to organic and non-organic honey samples can be observed in the phenograms of Figures 1 and 2.

To analyze the grouping, criteria were adopted to the definition of the groups in the graphic of the distances of the linking. This method is based on the identification of a Plato in a vertical sense, which means that many quality parameters are grouped because they are formed in the same distance of linking. This distance 


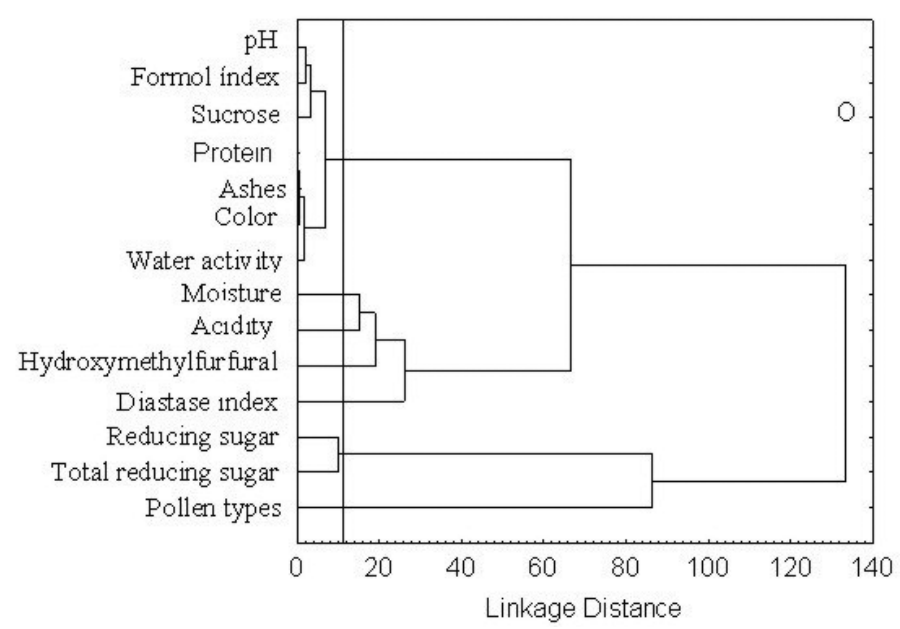

Fig. 1 - Phenogram obtained through the grouping analysis, using the medium Euclidean distance for organic honey samples of $A$. mellifera and physicochemical parameters selected.

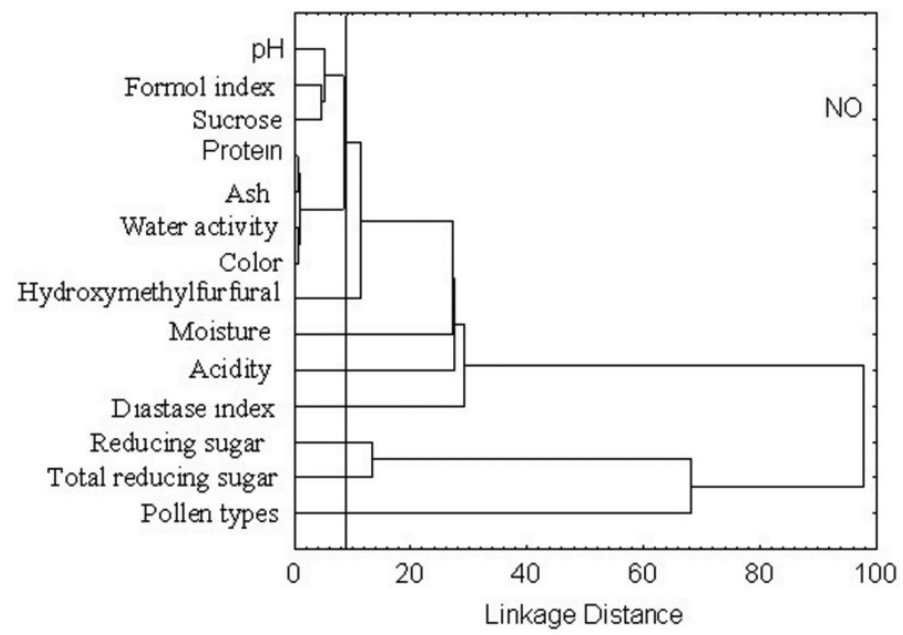

Fig. 2 - Phenogram obtained through the grouping analysis, using the medium Euclidean distance for non-organic honey samples of $A$. mellifera and physicochemical parameters selected.

can be an ideal cut point in the dendogram determining the number of groups that are formed, in this case, 11 for organic honey and nine to non-organic honey.

In Figure 1 it can be observed that organic honey samples were grouped into nine physicochemical parameters in two distinct groups, identified as: group I: $\mathrm{pH}$, formol index, sucrose, protein, ashes, color, and water activity, and group II: reducing sugar and total reducing sugar.

In Figure 2 it is observed that non-organic honey samples are grouped into seven physicochemical para- meters in one group: $\mathrm{pH}$, formol index and sucrose, protein, ashes, water activity, and color.

It was verified to organic honey samples from the triple frontier, a higher similarity to the physicochemical parameters in all the studied material, while to non-organic honey samples there is a higher heterogeneity, which confirms the influence of the geographic origin of the honey in the physicochemical characteristics evaluated.

The organic and non-organic honey samples of formed groups, according to the physicochemical char- 
acteristics, confirm that the geographic origin (climatic and environmental) interfered decisively in the studied parameters.

\section{ACKNOWLEDGMENTS}

The authors want to thank to the beekeepers and Diamante apiary by the supplying of honey samples. To "Conselho Nacional de Desenvolvimento Científico e Tecnológico do Brasil" (CNPq process number 151242/ 2004-6) for financial support.

\section{RESUMO}

O objetivo deste trabalho foi analisar e comparar 17 amostras de Apis mellifera mel, sendo 11 orgânicos e seis não orgânicos. As amostras foram analisadas quanto à umidade, hidroximetilfurfural, índice de diastase, atividade de água, cor, açúcares totais, açúcares redutores, sacarose, cinzas, viscosidade, condutividade elétrica, $\mathrm{pH}$, acidez e índice de formol. Com exceção da acidez, açúcar redutor e índice de diastase as médias dos demais parâmetros analisados diferiram entre os dois grupos. Todas as amostras de mel orgânico analisadas apresentaram valores de umidade entre 23,50 to $24,40 \%$. Das amostras de mel não orgânico analisadas, duas apresentaram quantidades de sacarose aparente acima do limite máximo estabelecido pela legislação brasileira. De acordo com as análises quantitativas dos sedimentos polínicos e a frequência dos tipos polínicos observados nas 17 amostras de mel analisadas, 41,20\% foram classificadas como monofloral e o restante como polifloral.

Palavras-chave: caracterização do mel, melissopalinologia, mel orgânico, análises físico-químicas.

\section{REFERENCES}

Almeida-Anacleto D And Marchini LC. 2004. Composição físico-química de amostras de méis de Apis mellifera L. provenientes do cerrado paulista. B Industr Anim 61: 161-172.

AOAC. 1990. Official methods of analysis of AOAC International. $15^{\text {th }}$ ed., Washington: AOAC, $1298 \mathrm{p}$.

ARChEnti A. 1984. Chemical composition of honeys from Chubut province (Argentina). Rev Cienc Agr 5: 12-28.

BARTH OM. 1970a. Análise microscópica de algumas amostras de mel. 1. Pólen Dominante. An Acad Bras Cienc 42: $351-366$
BARTH OM. 1970b. Análise microscópica de algumas amostras de mel. 2. Pólen Acessório. An Acad Bras Cienc 42: $571-590$.

BARTH OM. 1970c. Análise microscópica de algumas amostras de mel. 3. Pólen Isolado. An Acad Bras Cienc 42: $747-772$.

BARTH OM. 2004. Melissopalynology in Brazil: a review of pollen analysis of honeys, propolis and pollen loads of bees. Sci Agric 61: 342-350

BATH PK AND SINGH NA. 1999. Comparison between Helianthus annuus and Eucalyptus lanceolatus honey. Bee World 80: 61-69.

BIANCHI EM. 1989. Determinación de HMF en la miel. Santiago del Estero: Centro de Investigaciones Apícolas/ Universitad Nacional de Santiago del Estero, 8 p.

BobBIo FO AND BobBIo PA. 1999. Química do processamento dos alimentos. $3^{\mathrm{a}}$ ed., São Paulo: Varela, 144 p.

BogdanOV S. 1999. Honey quality and international regulatory standards: review by the international honey commission. Bee World 80: 61-69.

Bogdanov S, Martin P And LÜllmann C. 1997. Harmonised methods of the European Honey Commission. Apidol extra issue, p. 1-59.

BRASIL. 2000. Ministério da Agricultura. Instrução normativa $\mathrm{n}^{\circ} 11$, de 20 de outubro/2000. Regulamento técnico de identidade e qualidade do mel. (Available at: http://www.agricultura.gov.br/sda/dipoa/anexo).

BUAININ AM AND BATALHA MO. 2007. Cadeias produtivas de flores e mel. Brasília: MAPA/SPA.

Carvalho CAL, Marchini LC ANd Ross PB. 1999. Fontes de pólen utilizadas por algumas Apis mellifera L. e algumas espécies de Meliponinae. Bragantia 58: 49-56.

Codex Alimentarius. 2001. Revised Codex Standard for Honey. FAO/OMS. Rome, Italy, 7 p.

Costa leite SM, Albuquerque Mls, Trugo LC, QUinteiro LMC, BARTh OM, RIBEIRO M AND DE MARIA CAB. 1999. Determination of non-volatile compounds of different botanical origin Brazilian honey. Food Chem 65: 347-352.

Crane E. 1985. O livro do mel. São Paulo; Nobel, 226 p.

DAYRELl IO AND VitAL NC. 1991. Comparação entre dois métodos oficiais para determinação de hidroximetilfurfural (HMF) em mel brasileiro. Cienc Tecnol Aliment 1: 137-141.

DONER LW. 1977. The sugars of honey - a review. J Sci Food Agric 28: 443-456. 
DunNe LJ AND REUBEn BG. 1995. Application of the field theoretic method of Bohm and Pines to the determination of the activity coefficients of strong 1:1 electrolytes. Chem Phys Lett 242: 560-569.

ERdTMAN G. 1952. Pollen morphology and plant taxonomy. Angiosperms. Stockolm: Almqvist \& Wiksell, 539 p.

Evangelista J. 2000. Tecnologia de alimentos. São Paulo: Atheneu, $918 \mathrm{p}$.

FAEGRI K AND VAN DER PIJL L. 1979. The principles of pollination ecology. $3^{\text {rd }}$ ed., Oxford: Pergamon Press, $244 \mathrm{p}$.

FARIA JAF. 1993. Shelf life testing of honey. Cienc Tecnol Aliment 13: 58-66.

Flechtmann CHW, Caldas Filho CF, Amaral E ANd Arzolla JDP. 1963. Análise de méis do estado de São Paulo. Bol Ind An 21: 65-73.

FrIAS I AND HARDISSON A. 1992. Estudio de los parámetros analíticos de interés en la miel. II: Azúcares, cenizas y contenido mineral y color. Aliment 28: 41-43.

Huidobro JF AND Simal J. 1984. Determination of sugars in honey. Anal Bromatol 36: 247-264.

INMET. 2005. Instituto Nacional de Meteorologia. Ministério da Agricultura, Pecuária e Abastecimento. Prognóstico Trimestral - Dezembro/2004, Janeiro e Fevereiro/2005. Available at:

http:www.inmet.gov.br/climatologia/comboclimatologiaA.html

ISENGARD HD. 2001. Water content, one of the most important properties of food. Food Cont 12: 395-400.

JOLIFFE IT. 1973. Discarding variables in a principal component analysis. Appl Stat 21: 21-31.

Komatsu SS, Marchini LC And Moreti ACCC. 2002. Análises físico-químicas de amostras de méis de flores silvestres, de eucalipto e de laranjeira, produzidos por Apis mellifera L., 1758 (Hymenoptera, Apidae) no Estado de São Paulo. 2. Conteúdo de açúcares e de proteína. Cienc Tecnol Aliment 2: 143-146.

Koop T. 2002. The water activity of aqueous solutions in equilibrium with ice. Bull Chem Soc Jpn 75: 2587-2588.

Koop T, Luo B, TSIAS A AND PETER T. 2000. Water activity as the determinant for homogeneous ice nucleation in aqueous solution. Nature 406: 611-614.

LAsceve G AND Gonnet M. 1974. Analysis par radioactivation du contenu mineral d'un miel. Possibilité de préciser son origine géographique. Apidol 5: 201-223.

LORENZI H. 2000. Árvores brasileiras: manual de identificação e cultivo de plantas arbóreas nativas do Brasil. v. 12. $3^{\mathrm{a}}$ ed., Nova Odessa: Instituto Plantarium, $352 \mathrm{p}$.
Louveaux J, Maurizio A And Vorwohl G. 1978. Methods of Melissopalinology. Bee World 59: 139-157.

MAAK R. 1968. Geografia física do Estado do Paraná. Curitiba: Max Roesner, 350 p.

Marchini LC, Sodré GS AND Moreti AC. 2001. Características físico-químicas de amostras de mel de cinco diferentes espécies de eucaliptos. In: IV SIMPÓsIO LAtino AmericAno DE CIÊNCIA DE Alimentos. Resumo (p. 42). Campinas: SBCTA.

Marchini LC, Sodré GS And Moreti AC. 2004. Mel brasileiro: composição e normas. Ribeirão Preto: A.S. Pinto, $111 \mathrm{p}$.

MARChini LC AND SouzA BA. 2006. Composição físicoquímica, qualidade e diversidade dos méis brasileiros de abelhas africanizadas. In: $16^{\circ}$ CONGRESSO BRASILEIRo de Apicultura E $2^{\circ}$ Congresso Brasileiro de Meliponicultura, Aracajú. Anais..., 2006. v. 1CD.

MCGRegor SE. 1976. Insect Pollination of Cultivated Crop Plants. U.S. Department of Agriculture - Agricultural Research Service, Washington, DC, Handbook (496): 411.

Mendonça K, Marchini LC, Souza BA, AlmeidaAnACleto D And Moreti ACCC. 2008. Caracterização físico-química de amostras de méis produzidas por Apis mellifera L. em fragmento de cerrado no município de Itirapina, São Paulo. Cienc Rural 38: 1748-1753.

Moraes RM. 1994. Análise de mel. Pindamonhangaba, (Manual técnico): Centro de Apicultura Tropical: IZ/ SAA, $42 \mathrm{p}$.

PENG ZF AND PAN JG. 1994. Protein content in honey and its effects on precipitation of beverage. Food Sci 12: 6-8.

RAmalho M, KLEINERT-GiovanNini A AND IMPERATRIZ-FONSECA VL. 1990. Important bee plants for stingless bees (Melipona and Trigonini) and africanized honeybees (Apis mellifera) in neotropical habitats: a review. Apidol 21: 469-488.

Robinson WS, NowogrodzKi R AND Morse RA. 1989. The value of honey bees as pollinators of U.S. Crops: Part II. Am Bee J 129: 477-486.

RoubIK DW. 1995. Pollination of Cultivated Plants in the Tropics. Food Agric Org. U.N., Rome, Agricultural Bulletin (118): 196.

SEEmann P And NeIRA M. 1988. Tecnología de la producción apícola. Valdivia: Universidad Austral de Chile, Facultad de Ciencias Agrarias Empaste, 202 p.

SODRÉ GS, MARCHINI LC, ZUCCHI OLAD, NASCIMento Filho VF, Moreti ACCC And Otsuk IP. 
2005. Minerais encontrados em amostras de méis de Apis mellifera africanizada (Hymenoptera: Apidae) provenientes de alguns municípios do Estado do Ceará. Bol Ind An 62: 9-18.

Southwick EE AND Southwick L JR. 1992. Estimating the economic value of honey bees (Hymenoptera: Apidae) as agricultural pollinators in the United States. J Econ Entomol 85: 621-633.

Stonoga VI AND Freitas RJSD. 1991. Conteúdo de água e açúcares em mel de abelhas. Ceppa 9: 9-16.

Todd FE AND VANSEll GH. 1942. Pollen grains in nectar and honey. J Econ Entomol 35: 728-731.

Toledo VAT And Nogueira-Couto RH. 1999. Thermoregulation in colonies of Africanized and hybrids with Caucasian, Italian and Carniolan Apis mellifera honey bees. Braz Arch Biol Technol 42: 425-431.
Tosi E, Martinet R, Ortega M, Lucero H and Re E. 2008. Honey diastase activity modified by heating. Food Chem 106: 883-887.

Trombetta G, Di Bona C AND GRAZI E 2005. The transition of polymers into a network of polymers alters per se the water activity. Int J Biol Macromol 35: 15-18.

Tysset C And Rousseau M. 1981. Problem of microbes and hygiene of commercial honey. Rev Med Vet 132: 591-600.

White JUNIOR JW. 1975. Physical characteristics of honey. In: CRANE E. Honey a comprehensive survey, London: Heinemann, p. 207-239.

White Junior JW. 1994. The role of HMF and diastase assays in honey quality evaluation. Bee World 75: 104 107. 